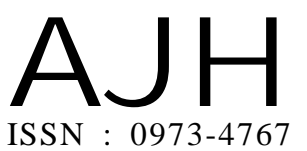

Article history :

Received : 24.08.2019

Revised : 11.11.2019

Accepted : 25.11.2019
RESEARCH PAPER

THE ASIAN JOURNAL OF HORTICULTURE

Volume 14 | Issue 2 | December, 2019 | 23-26

Visit us -www.researchjournal.co.in
DOI : 10.15740/HAS/TAJH/14.2/23-26

\section{Impact of buttom mushroom cultivation training to improve adoption status of farmers in district Sangrur}

\section{Ravinder Kaur}

ABSTRACT : Now-a-days people are more health conscious so they prefer nutritious diet to protect from diseases. Due to medicinal importance of mushrooms, cultivation of mushrooms have now become popular all over the world. In addition to its nutritious importance, cultivation of this crop is also good source of income. In Sangrur district, farmers are adopting it as additional source of income on large and small scale. Cultivation of mushroom is a scientific and technical approach. KVK Sangrur is providing practical training on mushroom cultivation during growing season. Mushroom cultivation can help reduce vulnerability to poverty and strengthens livelihoods through the generation of a fast yielding and nutritious source of food and a reliable source of income. Every year approximately 60 farmers got trained by KVK Sangrur and nearly thirty per cent farmers of district are adopting mushroom cultivation from small to large scale.

KEY WORDS : Mushroom, Cultivation, Nutricious

HOW TO CITE THIS ARTICLE : Kaur, Ravinder (2019). Impact of buttom mushroom cultivation training to improve adoption status of farmers in district Sangrur. Asian J. Hort., 14(2) : 23-26, DOI : 10.15740/HAS/TAJH/14.2/23-26. Copyright@2019: Hind Agri -Horticultural Society 